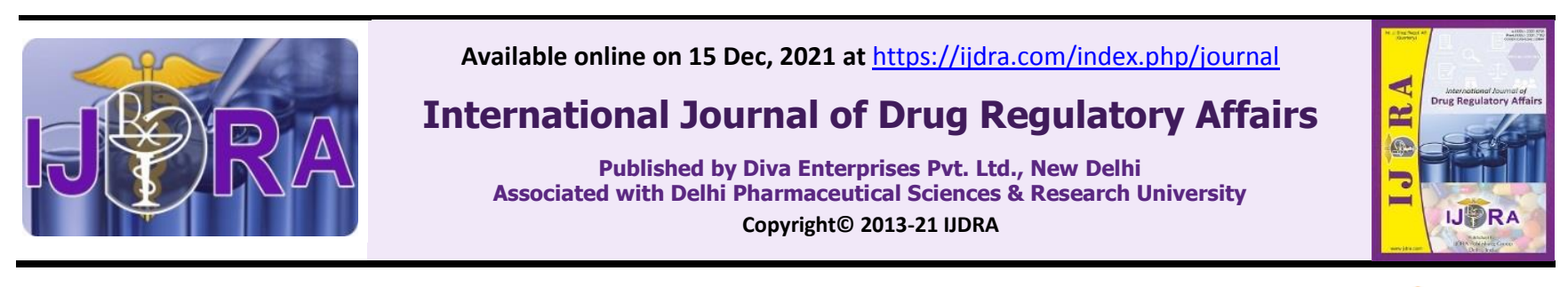

Review Article

Open $\odot$ Access

\title{
Significance of Personnel Hygiene Practices in Pharmaceutical Industry
}

\author{
Anuradha Shenvi, Krishnananda Kamath K*, E.V.S. Subrahmanyam, A R Shabaraya \\ Department of Quality Assurance, Srinivas College of Pharmacy, Valachil, Farangipete Post, Mangalore, Karnataka, India-574143
}

\begin{abstract}
Personnel hygiene is very important in the pharmaceutical industry to prevent or reduce any kind of contamination which can affect the quality of medicinal products. When it comes to delivering highest quality standards of pharmaceutical products, key hygiene factors must to be upheld. Good personnel hygiene policies and practices are the foundation for successful product safety and purity. They are the backbone of a meaningful Good manufacturing Practices (GMP). Proper personnel training and sanitation are of prime importance. Personnel engaged in the manufacture, processing, packing, or holding of a drug product shall wear clean clothing appropriate for the duties they perform. All personnel should undergo medical check-up which may be a prerequisite for safe working condition. Personnel hygiene policies and procedures are to be followed by all personnel including management, visitors, production, sanitation and maintenance staff, for reducing the chance of product contamination. Personnel hygiene practices and procedures play a vital role in pharmaceutical industry in order to achieve a good quality and safe product.
\end{abstract}

Keywords: Personnel Hygiene, Good Manufacturing Practices, contamination Training, Sanitation.

Article Info: Received 22 Oct. 2021; Review Completed 10 Dec. 2021; Accepted 13 Dec. 2021

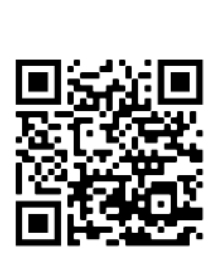

Cite this article as:

Shenvi A, Krishnananda Kamath $K^{*}$, Subrahmanyam E.V.S., Shabaraya A R. Significance of Personnel Hygiene Practices in Pharmaceutical Industry. Int J Drug Reg Affairs [Internet]. 2021 Dec 15 [cited 2021 Dec 15]; 9(4):1-5. Available from:

http://ijdra.com/index.php/journal/article/view/493

DOI: $10.22270 / i j$ ra.v9i4.493

*Corresponding author

\section{Introduction}

The pharmaceutical industry is cited as one of the top industries with the greatest level of risk, largely because employees are constantly dealing with substances that can prove lethal if mishandled. The correct manufacture of medicinal products relies upon people. For this reason there must be sufficient qualified personnel to carry out all the tasks which are the responsibility of the manufacturer. Good personnel hygiene practices are required in pharmaceutical industries to safeguard the product and avoid any form of contamination that affects quality of medicinal product. For any pharmaceutical company, employees are one of the most important assets to take care of. Employees in pharmaceutical plants are constantly being exposed to chemical and biological hazards which pose a severe threat to their health. Furthermore, lack of adequate safety standards and non-compliance may impact workforce productivity and have significant repercussions on business sustenance in the long run. Therefore, it is vital to have optimal health and safety practices while ensuring that all employees adhere to such regulations. (1)

Detailed hygiene programmes should be established and adapted to the different needs within the factory. They include procedures relating to the health, hygiene practices and clothing of personnel. Good personnel hygiene policies and practices are the foundation for successful product safety and quality assurance in all manufacturing facilities. They are the backbone of a meaningful approach to Good Manufacturing Practices. The standards set in personnel in manufacturing premises will outline the hygiene conditions not only to any customers but also to the staff, who must be provided with a very clear brief to understand without doubt the paramount importance of safe product handling. (2)

\section{Good Manufacturing Practice (GMP) guidelines}

Good Manufacturing Practice guidelines such as Schedule M, PICs, FDA's Current Good Manufacturing Practice (cGMP)- 21CFR $\S 211$ define the "current good manufacturing for the Finished Pharmaceuticals" As per 21 CFR 211.28 Personnel responsibilities and hygiene practices are defined.(3)

- Personnel engaged in the manufacture, processing, packing, or holding of a drug product shall wear clean clothing appropriate for the duties they perform. Protective apparel, such as head, face, hand, 
and arm coverings, shall be worn as necessary to protect drug products from contamination.

- Personnel shall practice good sanitation and health habits.

- Any person shown at any time (either by medical examination or supervisory observation) to have an apparent illness or open lesions that may adversely affect the safety or quality of drug products shall be excluded from direct contact with components, drug product containers, closures, in-process materials, and drug products until the condition is corrected or determined by competent medical personnel not to jeopardize the safety or quality of drug products.

- All personnel shall be instructed to report to supervisory personnel any health conditions that may have an adverse effect on drug products.

These procedures should be understood and followed in a very strict way by every person whose duties take him into the production and control areas. Every individual person is responsible for maintaining the quality of a medicinal product and hence collectively can be termed as "personnel". Good personnel hygiene is nothing but keeping oneself clean because many pathogenic or disease-causing bacteria come from operators / human beings working within the space. Hygiene is often defined as system of sanitary principles to preserve health. Personal hygiene refers to cleanliness of an individual person's body. $(4,5)$

\section{Personnel hygiene}

Personnel hygiene policies and procedures are implemented by all personnel including management, visitors, production, sanitation and maintenance staff at each company and in each facility, reducing the chance of product contamination. The transfer of contaminants can occur through an instantaneous route, like bacteria transferred from the body, skin, mouth, hands or hair to the product, or indirectly via their personnel clothing, footwear, utensils and other tools employed in their daily job. People are the most important "movers" within the plant and therefore a source of cross-contamination when moving from one processing area to other area. $(6,7)$
Personnel cleanliness should be maintained by all the personnel. (Fig 1) Personnel engaged in the manufacture, processing, packing, or holding of a drug product shall wear clean clothing appropriate for the duties they perform. (Fig 2 and 3) Protective apparel, such as head, face, hand, and arm coverings, shall be worn as necessary to safeguard drug products from contamination. Personnel shall practice good sanitation and health habits. The protective clothing, washing of hands and tools also avoiding foreign bodies left on the production lines should be targeted when the hygienic working practices are developed for maintenance personnel. (7-9)

\section{Medical check-up}

All personnel should undergo medical check-up which may be a prerequisite for safe working condition. Personnel not keeping well or having open wounds and skin infections are not allowed to enter the manufacturing facility. Those employees who are on medication for serious illness shall not enter in the facility and report the condition to the department head or concerned. If the person handles materials which are biologically active, it is necessary to limit the exposure of workers engaged in production to those materials. Apart of the control procedure like RLAFS, Bio-safety cabinets, Suits, hand gloves are to be ready to demonstrate that whatever system is put in place is effective and remains so. They may require a programme of environmental monitoring and effective monitoring. (10)

\section{Hand hygiene}

Hand hygiene has been described as the cornerstone and starting point in all infection control programs, with the hands of staff being the drivers and promoters of infections. Proper hand washing technique is the most important in maintain Personnel hygiene practices. Proper hand washing is especially important during this time of increased concern over global pandemic. Hands have two microbial floras: Resident and transient. Hand hygiene instructions (Fig 1) to be displayed in different areas in change room. (8-10)
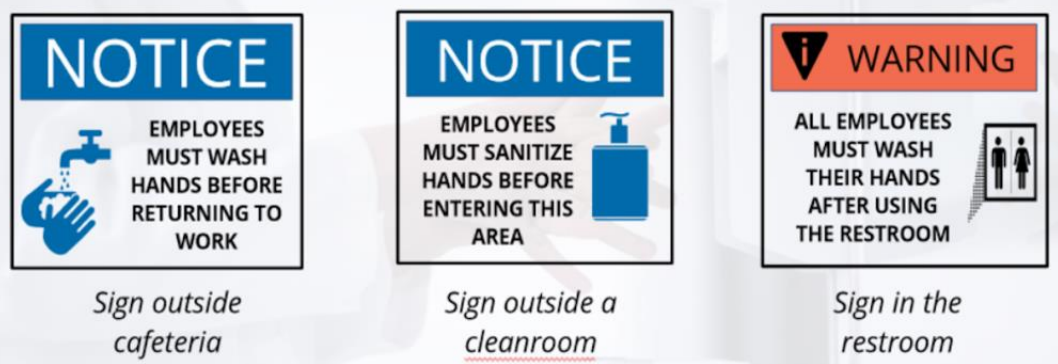

\section{Good instructions make all the difference}

Display clear instructions on hygiene where appropriate

Figure 1. Instructions to be displayed in different areas. (11) 


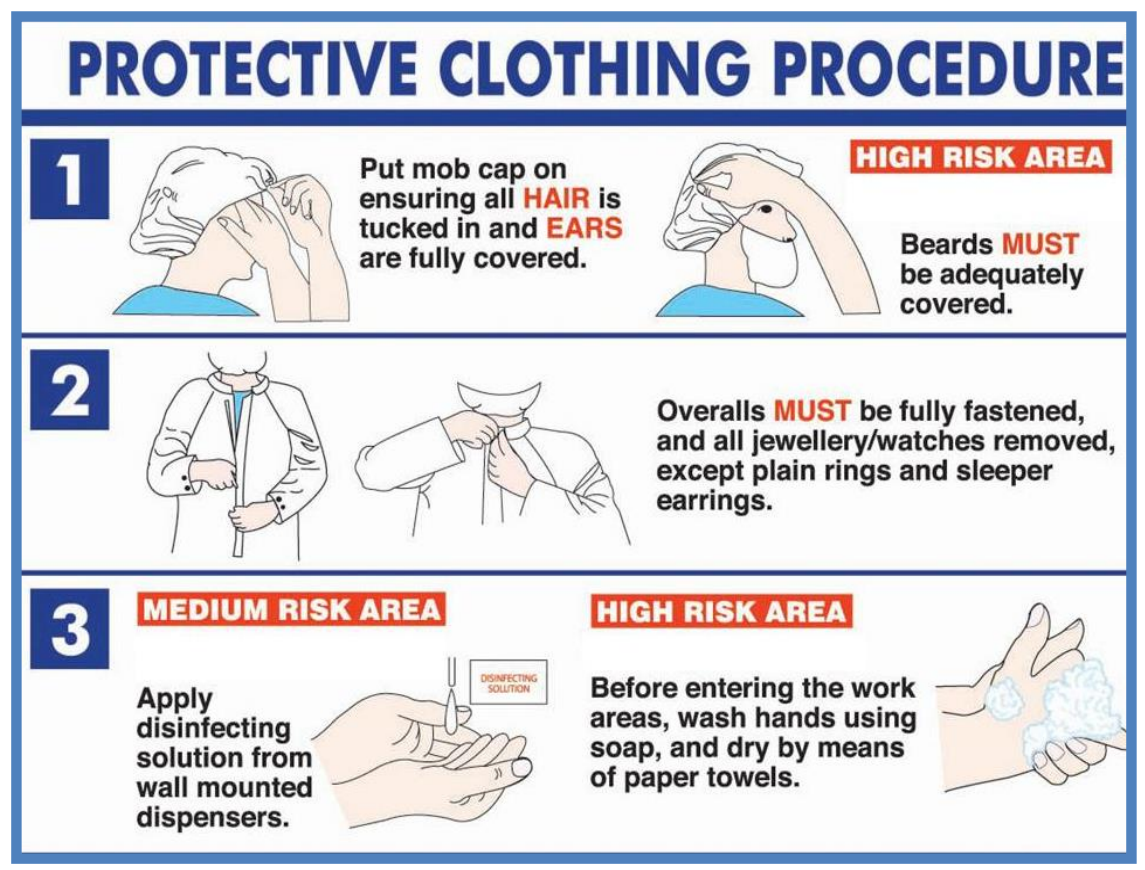

Figure 2. Primary gowning procedure (12)

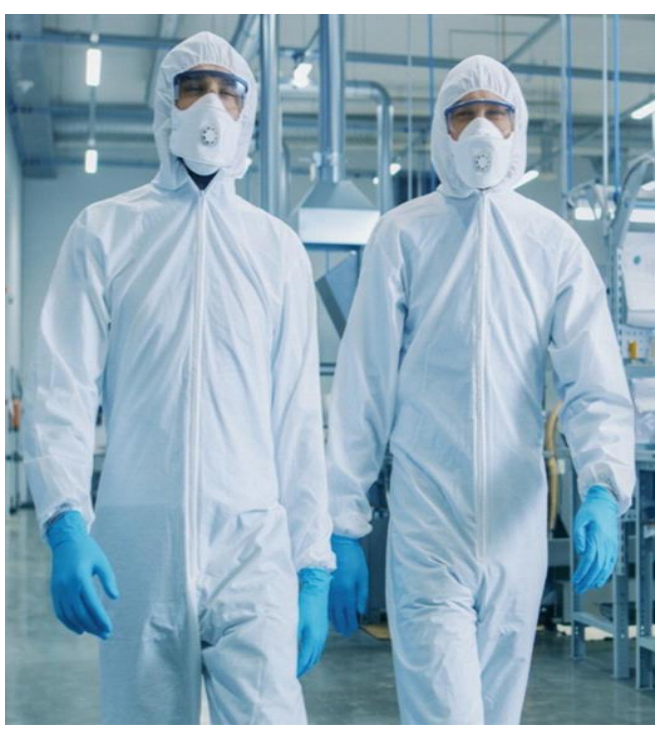

Figure 3. People at work with secondary gowning. (13)

\section{Training on Personnel Hygiene Practices}

Proper training on personnel hygiene should be imparted to any or all the personnel working within the facility. Having state-of-the-art manufacturing unit or stringent Quality Control measures is not enough to ensure superior hygiene in the pharmaceutical industry unless there are trained personnel to take the responsibility for ensuring high standards of sanitation and product quality.

Personnel employment, induction and training are of prime importance within the pharmaceutical industry. All new staff should bear an induction which is intended to introduce them to the rules and systems within the company, hygiene rules. The meaning of Good Manufacturing Practice (GMP) should also be explained to all the employees of the organisation. On the job training via a group of trainers within the company should even be evident to confirm that staffs fully understand their responsibilities and learn to take and follow written instructions and Good personnel hygiene practices. Primary change room procedures, Secondary change room procedures, Sterile gowning procedures and behavioural aspects in sterile area, Hand sanitisation etc. Training records should be maintained for each member of staff, and be kept updated at each review. Following points to be considered during training of personnel. (14-16)

- Educate and train all personnel regarding the importance of hygiene

- Implement use of hygienic work wear in specified work areas such as production facility, storage areas, loading and unloading unit, etc. Proper training should also be given regarding not using the hygiene clothing when away from 
the manufacturing environment or using the canteen, smoking area and toilets

- Such hygienic work wear should be available in sufficient numbers and must have a suitable design to prevent product contamination. It should also include caps for scalp hair and snoods for moustaches and beards

- Laundering of work wear should be implemented only by an approved contractor or in-house facility conforming to industry-defined criteria that validates the entire process. The following measures must be undertaken to ensure highest standards of hygiene in work wear laundering:

- Appropriate segregation of dirty and cleaned clothing

- Effective cleaning of work wear following industry standards

- Cleaned clothing must be supplied in contamination-free bags or covers

- Proper verification and validation of the laundry process should be in place and practiced thoroughly

- Implement use of high-performance hand disinfectants and dispensing systems to meet the highest standards of hand hygiene - one of the most critical preventive measures to avert the risk of germ \& impurity transmission by the hands of the personnel.

The use of proper and hygienic work wear is crucial to maintain high standards of pharmaceutical safety and ensure wellbeing of the end consumers. At the same time, effective measures must be taken to facilitate high quality cleaning, sterilisation and delivery of work wear to uphold hygiene at the workplace. (17)

\section{Conclusion}

In the current review it is justified that personnel hygiene practices and procedures play a vital role in pharmaceutical industry. In order to achieve a good quality and safe product the proper hygiene should be maintained. Personnel should undergo appropriate training on hygiene practices. Despite effective measures taken to maintain hygiene for production facilities, equipment, raw materials and product packaging, one of the primary sources of contamination are human beings. Proper hygiene is essential in the pharmaceutical industry to prevent any kind of contamination that can affect the quality of medicinal products. When it comes to delivering highest quality standards of pharmaceutical products, key hygiene factors need to be upheld. High levels of cleanliness and sanitation must be practiced through all stages of manufacturing through a comprehensive screening - from the personnel working in manufacturing plant to the production process.

\section{Acknowledgements}

We would like to express our sincere gratitude to management of Srinivas College of Pharmacy, Mangalore, and Mr. Maneesh Narkar, GM, Indaco Remedies Ltd, Verna, Goa to support us to carry out the project.
Financial Disclosure statement: The author received no specific funding for this work.

\section{Conflict of Interest}

The authors declare that there is no conflict of interest regarding the publication of this article.

\section{References}

1. Muddukrishna BS, Krishna TV, Kumar L, Reddy MS, Girish T, Pai KG. Personnel Hygiene in Pharmaceuticals: Its importance and requirements for personnel involved in the manufacturing of quality medicines. RJPT [Internet]. 2016 [cited 2021 Oct 09]; 9(10):1647-49. Available from: https://rjptonline.org/AbstractView.aspx?PID=2016-9-1030

2. Frederick T. The do's and don'ts of food plant personal hygiene practices. Food Safety Magazine [Internet]. 2005 [cited 2021 Oct 09]. Available from:

https://www.food-safety.com/articles/4689-the-dos-anddonts-of-food-plant-personal-hygiene-practices

3. FDA's Current Good Manufacturing Practice (cGMP) 21CFR § 211 define the "current good manufacturing for the Finished Pharmaceuticals [Internet]. 2021 Jan 10 [cited 2021 Oct 11] Available from:

https://www.accessdata.fda.gov/scripts/cdrh/cfdocs/cfcfr/ CFRSearch.cfm?CFRPart=211\& show $\quad F R=1$ \&subpartNode= 21:4.0.1.1.11.2

4. Hall J. Personal hygiene standards. In Food hygiene auditing [Internet]. Springer, Boston [cited 2021 Oct 09]; 1997:112-27. MA. Available from: https://link.springer.com/book/10.1007/978-1-4613-04517

5. Sutton S. Hand washing, hygiene, CGMP, and science. Journal of GXP Compliance [Internet]. 2010 [cited 2021 Oct 12]; 14(1):62 Available from:

https://www.ivtnetwork.com/sites/default/files/CGMPHyg iene_01.pdf

6. Rackham M, McHattie GV, Teasdale EL. Occupational hygiene measurement strategy in the pharmaceutical industry. Occupational Medicine [Internet]. 1989 Mar 1 [cited 2021 Oct 12]; 39(1):15-18. Available from: https://pubmed.ncbi.nlm.nih.gov/2716294/

7. Melero B, Diez AM, Rovira J. Basic Sanitation. Handbook of Fermented Meat and Poultry [Internet]. 2014 Oct 02 [cited 2021 Oct 09]; 441-49. Available from: https://onlinelibrary.wiley.com/doi/book/10.1002/978111 8522653

8. Aarnisalo K, Tallavaara K, Wirtanen G, Maijala R, Raaska L. The hygienic working practices of maintenance personnel and equipment hygiene in the Finnish food industry. Food control [Internet]. 2006 Dec 1 [cited 2021 Oct 13];17(12):1001-11. Available from:

https://cris.vtt.fi/en/publications/the-hygienic-workingpractices-of-maintenance-personnel-and-equip

9. Shobowale EO, Adegunle B, Onyedibe K. An assessment of hand hygiene practices of healthcare workers of a semiurban teaching hospital using the five moments of hand hygiene. Nigerian medical journal: journal of the Nigeria Medical Association [Internet]. 2016 May[cited 2021 Oct 13]; 57(3):150 Available from:

https://pubmed.ncbi.nlm.nih.gov/27397953/.

10. Premnath S. Handbook of pharmaceutical quality assurance. Bengaluru: $1^{\text {st }}$ Edition; 2016:63-82.

11. Instructions to be displayed in different areas [Internet]. [cited 2021 Oct 20]. Available from:

https://crambridge.in/portfolio/manufacturing/personalhygiene/

12. Gowning-procedure-food-packaging [Internet]. [cited 2021 Oct 20]. Available from: 
https://www.ifsqn.com/forum/index.php/gallery/image/77 -example-gowning-procedure-food-packaging/

13. People at work with secondary gowning [Internet]. [cited 2021 Oct 20]. Available from:

https://link.springer.com/chapter/10.1007/978-3-030-

33073-6_3

14. Bhusnure OG, Dongare RB, Gholve SB, Giram PS. Chemical hazards and safety management in pharmaceutical industry. Journal of Pharmacy Research [Internet]. 2018 [cited 2021 Oct 13];12(3):357-69. Available from:

https://innovareacademics.in/journals/index.php/ajpcr/arti cle/download/23160/13891/

15. Pai DR, Kamath KK, Subrahmanyam EVS, Shabaraya AR Personal Training for Pharmaceutical Industry. Int. J. of Pharm. Quality Assurance [Internet]. 2016 [cited 2021 Oct 12]; 7(3):55-61. Available from: https://ijpqa.openresearchjournals.com/index.php/ijpqa/art icle/view/117

16. Reham M, Haleem MY, Salem FA, Fatahallah LEA. Quality in the pharmaceutical industry - A literature review. Saudi Pharma J [Internet].. 2015 [cited 2021 Oct 12]; 23(5):463-69. Available from:

https://www.ncbi.nlm.nih.gov/pmc/articles/PMC4605917/

17. Maintaining Hygiene in the Pharmaceutical Industry: A Glimpse of Effective Practices to Implement 9.1. [Internet] 2020 [cited 2021 Oct 14] Available from: https://lindstromgroup.com/in/article/maintaininghygiene-in-the-pharmaceutical-industry-a-glimpse-ofeffective-practices-to-implement/ 